\title{
Effects of Cutting Interval between Harvests on Dry Matter Yield and Nutritive Value in Alfalfa
}

\author{
Doohong Min \\ Department of Agronomy, Kansas State University, Manhattan, KS, USA \\ Email:dmin@ksu.edu
}

Received 12 May 2016; accepted 14 June 2016; published 17 June 2016

Copyright (C) 2016 by author and Scientific Research Publishing Inc.

This work is licensed under the Creative Commons Attribution International License (CC BY). http://creativecommons.org/licenses/by/4.0/

(c) (i) Open Access

\begin{abstract}
Understanding the relationship between dry matter yield and nutritive value throughout the growing season will help optimize the cutting intervals between harvests in alfalfa (Medicago sativa L.). The Ogallala Aquifer is a very important water source when growing alfalfa in Southwest Kansas and unfortunately, the water level of the Ogallala Aquifer is shrinking. The objective of this study was to determine the optimum cutting interval that optimizes dry matter yield and nutritive values of alfalfa. Alfalfa was harvested with different cutting intervals, i.e., every 28, 35, 42 and 49 day, which was equivalent of 5, 4, 4, and 3 cuttings per year, respectively in 2013 and 2014 . Based on 2-yr total yield, by delaying alfalfa harvest by 21 days, i.e., from every 28th day to 49th day, alfalfa yield increased by $2.25 \mathrm{Mg} / \mathrm{ha}$ whereas by $5.58 \mathrm{Mg} / \mathrm{ha}$ by delaying cutting intervals from every 28th day to 42nd day. Although harvesting alfalfa every 42nd day had the same cutting frequency as the 35 th day treatment (i.e., 4 cuttings per year), the treatment harvesting every $42 \mathrm{nd}$ day had significantly higher alfalfa yield than 35th day cutting interval. Alfalfa yield increased by approximately $20 \%$ by delaying one week for harvesting alfalfa from 35th to 42 nd day interval, based on dry matter yields of 2013 and 2014. As cutting interval increased from every 28th to 49th day, crude protein (CP) content decreased. In contrast to CP, acid detergent fiber and neutral detergent fiber increased as the cutting interval and stage of maturity increased in 2013 and 2014. The results suggest that alfalfa producers in Southwest Kansas possibly could reduce the cutting frequency from 5 to 4 per year. Cutting interval of every 42nd day between harvests appears to be the optimum when considered a dry matter yield and nutritive values in alfalfa.
\end{abstract}

\section{Keywords}

Alfalfa, Cutting Interval, Cutting Frequency, Dry Matter Yield, Forage Quality 


\section{Introduction}

Alfalfa is one of the most important hays as a cash crop in Southwest Kansas producing more than $70 \%$ of the alfalfa in Kansas [1] and is a very important forage to the dairy and beef industry in Kansas. Alfalfa is harvested five times a year in Southwest Kansas under irrigation, and proper harvest managements such as cutting intervals between harvests is essential to profitable alfalfa production, particularly in the manipulation of forage quality and yield. Also, the water level of Ogallala Aquifer in Kansas is decreasing every year. Within reason, fewer cuttings per season might result in higher yield per season but possibly at the expense of forage quality; forage dry matter yield, however, may be more important than forage quality under severe drought conditions in which the forage supply is limited. Several studies reported that as the cutting interval between harvests increased, dry matter yield of alfalfa generally increased while forage quality decreased [2]-[5]. Kallenbach et al. [4] reported that alfalfa harvested four times yielded 7\% more per year than when harvested five times, and 28\% more than when harvested six times in Missouri, USA. Albrecht et al. [6] and Sheaffer et al. [5] also reported that the decline in forage quality with increasing cutting interval between harvests was associated with increasing stem growth and decreasing leaf proportion, and decreasing stem nutritive value. Different purposes of alfalfa, i.e., hay vs. grazing showed different response to cutting frequency. Brummer and Bouton [7] [8] suggested that grazing-type alfalfa was more tolerant of frequent cuttings than hay-types alfalfa. No research on alfalfa was conducted to determine the optimum cutting intervals between harvests in Kansas. The objective of this study was to determine the optimum cutting interval that optimized dry matter yield and nutritive values of alfalfa in Southwest Kansas, USA.

\section{Materials and Methods}

This research was conducted at the Kansas State University Southwest Research-Extension Center, Garden City $\left(37^{\circ} 588^{\prime} 31 " \mathrm{~N}, 100^{\circ} 51^{\prime} 51^{\prime \prime} \mathrm{W}\right)$ in Kansas, USA. The weather information during growing seasons in 2013, 2014, and 30 year average are shown in Table 1. On average, there was higher rainfall in 2014 than that of 2013 and it

Table 1. Monthly 30-year temperature and precipitation averages and departures from average for 2013 an 2014 in Garden City, KS.

\begin{tabular}{|c|c|c|c|c|}
\hline \multirow[b]{2}{*}{ Item } & \multirow[b]{2}{*}{ Month } & \multirow{2}{*}{$\begin{array}{l}\text { 30-Year } \\
\text { Average }\end{array}$} & \multicolumn{2}{|c|}{ Departure from average } \\
\hline & & & 2013 & 2014 \\
\hline \multirow[t]{8}{*}{ Temperature, ${ }^{\circ} \mathrm{C}$} & March & 14.2 & -1 & -1.8 \\
\hline & April & 19.6 & -2.9 & 0.2 \\
\hline & May & 24.7 & 0.3 & 0.2 \\
\hline & June & 30.3 & 2.3 & 0.6 \\
\hline & July & 33.4 & 0.6 & -0.9 \\
\hline & August & 32.2 & $\mathbf{0}$ & 1.1 \\
\hline & September & 28 & 2.7 & 0.7 \\
\hline & October & 21.1 & -0.2 & 2.2 \\
\hline \multirow[t]{8}{*}{ Precipitation, mm } & March & 31.24 & -27.94 & -24.89 \\
\hline & April & 44.2 & -37.08 & -26.67 \\
\hline & May & 76.2 & -44.45 & -60.2 \\
\hline & June & 78.74 & -32 & 187.96 \\
\hline & July & 71.12 & -14.48 & 25.65 \\
\hline & August & 63.75 & 90.93 & -13.21 \\
\hline & September & 36.07 & 10.41 & 32.77 \\
\hline & October & 30.99 & -8.64 & 14.22 \\
\hline
\end{tabular}


was a little warmer in 2013 than that of 2014. The soil type for the study was a deep, well drained Ulysses silt loam (fine-silty, mixed, mesic Aridic Haplustoll) and a soil pH was 8.4.Phosphorus and potassium were 40 and $820 \mathrm{ppm}$, respectively and the organic matter was $1.5 \%$. Alfalfa was drilled $(20 \mathrm{~cm}$ row spacing) into a prepared seedbed at $22.4 \mathrm{~kg} \cdot \mathrm{ha}^{-1}$ in September 2012. Alfalfa was harvested with different cutting intervals, i.e., every 28th, 35th, 42nd and 49th day, which is equivalent of 5, 4, 4, and 3 cuttings per year, respectively in 2013 and 2014to determine the optimum cutting interval and frequency in alfalfa. The plot size was $3.3 \mathrm{~m} \times 3.3 \mathrm{~m}$ and forage samples were harvested using $0.45 \mathrm{~m} \times 0.45 \mathrm{~m}$ quadrat with a pruner at a 5 -cm stubble height. Samples collected from the quadrat were dried in forced-air ovens at $65^{\circ} \mathrm{C}$ for 72 hours to determine dry matter content and calculate dry matter yield (Mg/ha). After drying, samples were ground to pass a 1-mm Wiley mill screen. Ground forage samples were sent to a commercial laboratory (ServiTech in Dodge City, KS). Forage quality measurements such as crude protein (CP), acid detergent fiber (ADF), neutral detergent fiber (NDF), and total digestible nutrients (TDN) were analyzed using a near infrared spectroscopy (NIRS) [9]. Relative feed value was estimated from ADF and NDF values: DDM $=$ Digestible Dry Matter $=88.9-(0.779 \times \%$ ADF $)$ and DMI $=$ Dry Matter Intake $(\%$ of $\mathrm{BW})=120 /(\% \mathrm{NDF}) ; \mathrm{RFV}=(\mathrm{DDM} \times \mathrm{DMI}) / 1.29$. The experimental design was randomized complete block with 4 replications. When the $F$-test was significant $(P<0.05)$, Fisher's protected LSD was used for multiple comparisons $(\alpha=0.05)[10]$.

\section{Forage Dry Matter Yield}

The mean response for alfalfa dry matter yield to cutting interval treatments in 2013, 2014, and a 2-year totals are shown in Table 2. Alfalfa dry matter yields were affected by cutting intervals ranging from every 28th to 49th day between cuttings. Alfalfa yield increased as cutting intervals increased up to every 42nd days in 2013, 2014 and 2-year total and then either decreased (in 2013 and 2-year total yield) or made plateau (in 2014 yield). No significant difference in alfalfa yield was found between 28th and 49th day treatments in 2013 but harvesting alfalfa every 49th day had significantly $(P<0.05)$ higher dry matter yield than cutting alfalfa every 28th day in 2014. Based on 2-yr total yield, by delaying alfalfa harvest by 21 days, i.e., from every 28th day to 49th day, alfalfa yield increased by $2.25 \mathrm{Mg} / \mathrm{ha}$ whereas by $5.58 \mathrm{Mg} /$ ha by delaying cutting intervals from every 28th day to 42nd day. This indicates that alfalfa yield doesn't necessarily increase linearly if the cutting interval of alfalfa is delayed too long and even alfalfa dry matter yield decreased by about $16 \%$ when alfalfa was harvested every 49th day (3 cuttings per year) compared with treatment harvesting alfalfa every 42nd day (4 cuttings per year). This also implies that delaying alfalfa harvest too long, i.e., every 49th day cutting might decrease alfalfa yield possibly resulting from some dry matter loss of older shoots in the lower side of alfalfa. These data were similar to those reported by Kallenbach et al. [4] in Missouri, who found that harvesting alfalfa four times per year yielded an average of $0.8 \mathrm{Mg} / \mathrm{ha}$ more per year than alfalfa harvested five times per year over 4 year period. Based on the 2-yr total dry matter yield in the current study, cutting alfalfa every 42nd day appeared significantly higher yield than other cutting treatments. Although harvesting alfalfa every 42nd day had the same cutting frequency (i.e., 4 cuttings per year as the 35 day treatment), the treatment harvesting every 42nd day interval had significantly higher alfalfa yield than 35 day cutting interval. This suggests that alfalfa yield increased by approximately $20 \%$ by delaying one week for harvesting alfalfa from 35th to 42 nd day interval, based on dry matter yields of 2013 and 2014. Sheaffer et al. [5] reported that the optimum harvest interval for alfalfa was about the 35th day in Minnesota.

Table 2. Alfalfa dry matter yield (Mg/ha) as affected by cutting intervals between harvests in 2013, 2014, and 2 year total yield.

\begin{tabular}{cccc}
\hline Cutting intervals (days) & $\mathbf{2 0 1 3}$ & $\mathbf{2 0 1 4}$ & 2-yr totals \\
\hline $\mathbf{2 8}$ & $6.76 \mathrm{c}$ & $8.78 \mathrm{~b}$ & $15.54 \mathrm{c}$ \\
$\mathbf{3 5}$ & $7.88 \mathrm{~b}$ & $9.07 \mathrm{~b}$ & $16.95 \mathrm{~b}$ \\
$\mathbf{4 2}$ & $9.56 \mathrm{a}$ & $11.56 \mathrm{a}$ & $21.12 \mathrm{a}$ \\
$\mathbf{4 9}$ & $6.81 \mathrm{bc}$ & $10.98 \mathrm{a}$ & $17.79 \mathrm{~b}$ \\
\hline
\end{tabular}

${ }^{\dagger}$ Lower case letter within the same row denote statistical differences between cutting intervals $(\alpha=0.05$ ). 


\section{Forage Quality}

The mean response for nutritive values to cutting frequency treatments in 2013 is shown in Table 3 and Table 4. Nutritive values (CP, ADF, NDF, TDN, and RFV) of alfalfa were affected by cutting frequency when averaged over the cuttings in 2013 and 2014. The overall nutritive values of alfalfa harvested in 2013 were higher than those in 2014 although it was wetter during May-September in 2014 than those in 2013. As the cutting interval increased from every 28th to 49th days, crude protein content decreased. This might be due to higher maturity by harvesting less frequently such as the every 49th day cutting treatment. Crude protein content at the most frequent cutting treatment (5 cuttings per year) was significantly $(P<0.05)$ higher than other cutting frequency treatments in both 2013 and 2014. This might be due to a lower maturity stage for the most frequently harvesting treatment (i.e., every 28th day) than rest of cutting intervals. No significant difference was found between every 35th and 42nd day cutting frequency treatments. By delaying the harvest i.e. 5 and 18 more days compared to harvesting every 28 day, the crude protein content reduced by 4\% and 6\%, respectively in 2013 (Table 4). Unlike 2013, the CP content between 35 and 42 day cutting interval treatments was not significantly different in 2014.

In contrast to crude protein, acid detergent fiber increased as the cutting interval and stage of maturity increased in 2013 and 2014. The most frequent harvesting treatment, i.e., cutting every 28th day had the lowest ADF content as compared to other cutting treatments. The ADF difference between the most and least cutting intervals was about $6 \%$ and $10 \%$, respectively indicating that as the cutting interval increased, the ADF content increased. Cutting alfalfa every 35th day had significantly $(P<0.05)$ lower ADF than cutting every 42nd day although these two treatments had the same number of cuttings ( 4 times per year). This indicates that ADF contents can be increased by delaying alfalfa harvesting.

Similar to ADF, the neutral detergent fiber contents increased as the cutting interval increased. The most frequent cutting treatment (i.e., 28th day) had the lowest NDF as compared to other cutting treatments. Although a cutting frequency between every 35th and 42nd day interval was the same (i.e., 4 cuttings per year), cutting al-

Table 3. Average nutritive values of alfalfa as affected by cutting intervals between harvests in 2013.

\begin{tabular}{cccccc}
\hline & Cutting Intervals (days) & & & \\
\hline Measurements & $\mathbf{2 8}$ & $\mathbf{3 5}$ & $\mathbf{4 2}$ & $\mathbf{4 9}$ \\
\hline CP (\%) & $29.7 \mathrm{a}$ & $26.0 \mathrm{~b}$ & $25.9 \mathrm{~b}$ & $23.9 \mathrm{c}$ \\
ADF (\%) & $21.5 \mathrm{~d}$ & $24.0 \mathrm{c}$ & $25.5 \mathrm{~b}$ & $27.7 \mathrm{a}$ & $34.9 \mathrm{a}$ \\
NDF (\%) & $27.7 \mathrm{~d}$ & $30.4 \mathrm{c}$ & $32.7 \mathrm{~b}$ & $71.5 \mathrm{~b}$ & $69.1 \mathrm{c}$ \\
TDN (\%) & $75.6 \mathrm{a}$ & $72.9 \mathrm{~b}$ & $205 \mathrm{~b}$ & $182 \mathrm{c}$ \\
\hline RFV & $245 \mathrm{a}$ & $220 \mathrm{~b}$ & & \\
\hline
\end{tabular}

${ }^{\dagger} \mathrm{CP}$; crude protein, ADF; acid detergent fiber, NDF; neutral detergent fiber, TDN; total digestible nutrients, RFV; relative feed value. ${ }^{\dagger}$ Lower case letter within the same row denote statistical differences between cutting intervals $(\alpha=0.05)$.

Table 4. Average nutritive values of alfalfa as affected by cutting intervals between harvests in 2014.

\begin{tabular}{|c|c|c|c|c|}
\hline \multicolumn{5}{|c|}{ Cutting Intervals (days) } \\
\hline Measurements & 28 & 35 & 42 & 49 \\
\hline CP (\%) & $30.5 a$ & $27.9 \mathrm{~b}$ & $22.8 \mathrm{c}$ & $22.2 \mathrm{c}$ \\
\hline ADF (\%) & $25.4 \mathrm{~b}$ & $27.9 \mathrm{~b}$ & $35.1 \mathrm{a}$ & 35.2 \\
\hline NDF (\%) & $33.3 b$ & $34.2 b$ & $44.1 \mathrm{a}$ & $45.5 \mathrm{a}$ \\
\hline TDN (\%) & $72.5 \mathrm{a}$ & $69.2 \mathrm{a}$ & $61.7 \mathrm{c}$ & $60.3 \mathrm{c}$ \\
\hline RFV & 195a & $184 \mathrm{~b}$ & 131c & $125 \mathrm{c}$ \\
\hline
\end{tabular}

${ }^{\dagger} \mathrm{CP}$; crude protein, ADF; acid detergent fiber, NDF; neutral detergent fiber, TDN; total digestible nutrients, RFV; relative feed value. ${ }^{\dagger}$ Lower case letter within the same row denote statistical differences between cutting intervals $(\alpha=0.05)$. 
falfa every 35th day treatment had significantly $(P<0.05)$ lower NDF than the every 42nd day cutting interval treatment. This indicates that NDF content can be increased with increased cutting interval resulting in more fibers in alfalfa plants. The total digestible nutrients (TDN) had a very similar trend to ADF and NDF contents showing as cutting intervals increased from every 28th day to 49th day, the TDN decreased by about $6 \%$.

As one of the important hay quality index, relative feed value (RFV) decreased as the cutting interval increased. The most frequent cutting treatment (5 cuttings per year) had significantly $(P<0.05)$ higher RFV than other cutting treatments and there was a difference by 63 and 70 in 2013 and 2014, respectively as compared with the least cutting treatment. No significant difference was found between cutting every 35th and 42nd day in 2013 and this trend was the same in crude protein and total digestible nutrients. Unlike 2013, harvesting alfalfa every 35th days had significantly $(P<0.05)$ higher RFV than cutting alfalfa every 42nd day in 2014 although these two cutting intervals had 4 cuttings per year with different stages of maturity. Overall, forage quality increased as cutting frequency increased, which was consistent with other findings [4] [11] [12].

\section{Conclusion}

Cutting interval between harvests affected alfalfa yield and nutritive values in Southwest Kansas. Based on 2-yr total dry matter yield in 2013 and 2014, alfalfa yield increased by $2.25 \mathrm{Mg}$ /ha by delaying alfalfa harvest by 21 days, i.e., from every 28th day to 49th day whereas by $5.58 \mathrm{Mg} /$ ha by delaying cutting intervals from every 28th day to 42nd day. Although harvesting alfalfa every 42nd day had the same cutting frequency as the 35th day treatment (i.e., 4 cuttings per year), the treatment harvesting every 42nd day interval between harvests had significantly higher alfalfa yield than 35th day cutting interval. Alfalfa yield increased by approximately $20 \%$ by delaying one week for harvesting alfalfa from 35th to 42nd day interval, based on dry matter yields of 2013 and 2014. As cutting interval increased from every 28th to 49th day, crude protein content decreased. In contrast to crude protein, both ADF and NDF increased as the cutting interval and stage of maturity increased in 2013 and 2014. The results suggest that alfalfa producers in Southwest Kansas possibly could reduce the cutting frequency from 5 to 4 per year. Cutting interval of every 42nd day (4 cuttings per year) between harvests appears to be the optimum when considered a dry matter yield and nutritive values in alfalfa.

\section{Acknowledgements}

The author wishes to thank Anthony Zukoff at the K-State Southwest Research and Extension Center in Garden City, KS for his excellent technical assistance with alfalfa harvestings, plot maintenance, data collection and statistical analysis.

\section{References}

[1] USDA Census of Agriculture (2012). http://www.agcensus.usda.gov/Publications/2012

[2] Brink, G. and Marten, G. (1989) Harvest Management of Alfalfa-Nutrient Yield vs Forage Quality and Relationship to Persistence. Journal of Production Agriculture, 2, 32-36. http://dx.doi.org/10.2134/jpa1989.0032

[3] Brink, G., Hall, M., Shewmaker G., Undersander D., Martin, N. and Walgenbach, R. (2010) Changes in Alfalfa Yield and Nutritive Value within Individual Harvest Periods. Agronomy Journal, 102, 1274-1282. http://dx.doi.org/10.2134/agronj2010.0080

[4] Kallenbach, R., Nelson, C. and Coutts, J. (2002) Yield, Quality, and Persistence of Grazing- and Hay-Type Alfalfa under Three Harvest Frequencies. Agronomy Journal, 94, 1094-1103. http://dx.doi.org/10.2134/agronj2002.1094

[5] Sheaffer, C. and Marten, G. (1990) Alfalfa Cutting Frequency and Date of Fall Cutting. Journal of Production Agriculture, 3, 486-491. http://dx.doi.org/10.2134/jpa1990.0486

[6] Albrechet, K.A., Wedin, W.F. and Buxton, D.R. (1987) Cell-Wall Composition and Digestibility of Alfalfa Stems and Leaves. Crop Science, 27, 735-741. http://dx.doi.org/10.2135/cropsci1987.0011183X002700040027x

[7] Brummer, C. and Bouton, J. (1991) Plant Traits Associated with Grazing-Tolerant Alfalfa. Agronomy Journal, 83, 9961000. http://dx.doi.org/10.2134/agronj1991.00021962008300060014x

[8] Brummer, C. and Bouton, J. (1992) Physiological Traits Associated with Grazing-Tolerant Alfalfa. Agronomy Journal, 84, 139-143. http://dx.doi.org/10.2134/agronj1992.00021962008400020003x

[9] Shenk, J.S. and Westerhaus, M.O. (1991) Population Definition, Sample Selection, and Calibration Procedures for near Infrared Reflectance Spectroscopy. Crop Science, 31, 469-474. 
http://dx.doi.org/10.2135/cropsci1991.0011183X003100020049x

[10] Steele, R. and Torrie, J. (1980) Principles and Procedures of Statistics: A Biometrical Approach. 2nd Edition, McGraw-Hill, New York.

[11] Kust, C.A. and Smith, D. (1961) Influence of Harvest Management on the Level of Carbohydrate Reserves, Longevity of Stands, and Yields of Hay and Protein from Vernal Alfalfa. Crop Science, 1, 267-269. http://dx.doi.org/10.2135/cropsci1961.0011183X000100040011x

[12] Moyer, J.R., Fraser, J., Rode, L.M. and Topinka, A.K. (1999) Effects of Growth Stage-Based Alfalfa Harvest on Weed Encroachment and Resultant Quality. Canadian Journal of Plant Science, 79, 243-247. http://dx.doi.org/10.4141/P98-059 